\title{
THE PREVALENCE OF CELIAC DISEASE AMONG PATIENTS WITH FAMILIAL MEDITERRANEAN FEVER
}

\author{
Sedat IȘIKAY', Nurgül IȘIKAY² and Halil KOCAMAZ ${ }^{3}$
}

\begin{abstract}
Context - Familial Mediterranean Fever and celiac disease are both related to auto-inflammation and/or auto-immunity and they share some common clinical features such as abdominal pain, diarrhea, bloating and flatulence. Objective - We aimed to determine the association of these two diseases, if present. Methods - Totally 112 patients diagnosed with Familial Mediterranean Fever and 32 cases as healthy control were included in the study. All participants were examined for the evidence of celiac disease, with serum tissue transglutaminase IgA levels (tTG IgA). Results - Totally 144 cases, 112 with Familial Mediterranean Fever and 32 healthy control cases were included in the study. tTG IgA positivity was determined in three cases with Familial Mediterranean Fever and in one case in control group. In that aspect there was no significant difference regarding the tTG IgA positivity between groups $(P=0.81)$. Duodenum biopsy was performed to the tTG IgA positive cases and revealed Marsh Type $3 \mathrm{~b}$ in two Familial Mediterranean Fever cases and Marsh Type 3c in the other one while the biopsy results were of the only tTG IgA positive case in control group was Marsh Type 3b. In HLA evaluation of the celiac cases; HLA DQ2 was present in two celiac cases of the Familial Mediterranean Fever group and in the only celiac case of the control group while HLA DQ8 was present in one celiac case of the Familial Mediterranean Fever group. Conclusion - We did not determine an association of Familial Mediterranean Fever with celiac disease. Larger studies with subgroup analysis are warranted to determine the relationship of these two diseases.
\end{abstract}

HEADINGS - Familial Mediterranean Fever. Celiac disease. Child.

\section{INTRODUCTION}

Familial Mediterranean Fever (FMF) is a hereditary disease of chronic autoimmune inflammation characterized by frequently relapsing fever, polyserositis, and/or arthritis ${ }^{(21)}$. The gene responsible for FMF (MEFV gene) is located on the short arm of chromosome 16 and encodes an immuno-regulatory protein called pyrin ${ }^{(1)}$. Pyrin has been determined to have an important role in the activation of interleukin 1 beta (IL-1 $\beta$ ) and the overproduction of IL-1 $\beta$ is reported to be responsible for $\mathrm{FMF}^{(25)}$. In that aspect, FMF is an auto- inflammatory disease, meaning that it is a disorder of inappropriate inflammation ${ }^{(11)}$. It is clearly known that auto-inflammatory diseases may overlap with, or mimic, autoimmune diseases ${ }^{(12)}$.

On the other hand, celiac disease (CD) is an autoimmune disorder, caused by a gluten intolerance ${ }^{(18)}$. Patients with CD may present with gastrointestinal symptoms such as diarrhea, steatorrhea, weight loss, bloating, flatulence, and abdominal pain in addition to non-gastrointestinal abnormalities including liver disease, iron deficiency anemia, bone disease, and skin disorders ${ }^{(7,24)}$. In CD, infiltration of both CD4+ and CD8+ T cells in the small intestine are induced by dietary gluten ${ }^{(10)}$. In pathogenesis of $C D$, the inflammatory cytokine IL-15 was determined to be up-regulated within celiac intestinal mucosa, and suspected to promote inflammation ${ }^{(4)}$. In diagnosis of $\mathrm{CD}$, assays for anti-tissue transglutaminase IgA (tTG $\operatorname{IgA}$ ) and anti-endomysial IgA (EMA) are regarded as serological screening tools with their high specificities and sensitivities ${ }^{(23)}$. As CD is an immune-mediated enteropathy, it has been associated with some autoimmune and inflammatory diseases with common pathogenic mechanisms ${ }^{(9,17)}$.

Since FMF and CD are both related to auto-inflammation and/or auto-immunity and they share some common clinical features especially regarding the gastrointestinal system; we aimed to determine the association of these two diseases. Since the symptoms of these two diseases may mimic each other, clinicians should be aware of this relationship, if present.

\footnotetext{
Declared conflict of interest of all authors: none Disclosure of funding: no funding received

${ }^{1}$ Department of Pediatric Neurology, Gaziantep Children's Hospital; ${ }^{2}$ Department of Anesthesiology, Medicine Faculty, Gaziantep University; ${ }^{3}$ Department of Pediatric Gastroenterology, Gaziantep Children's Hospital. Gaziantep, Turkey.

Correspondence: M.D. Ședat Ișıkay. Department of Pediatric Neurology, Gaziantep Children's Hospital, 27500, Șehitkamil, Gaziantep, Turkey. E-mail: dr.sedatisikay@
} mynet.com 


\section{METHODS}

This is a prospective, cross-sectional study. Totally 112 patients diagnosed with FMF in the Pediatric Gastroenterology Department of Gaziantep Children Hospital between 2012 and 2014, and 32 Children as healthy controls were included in the study. Informed consent was obtained from the parents of all participants. The study protocol was approved by the Ethics Committee of Gaziantep University.

Age and gender were recorded in all cases. Among FMF cases, the disease age, colchicine usage period, the type of FMF gene mutations were also recorded. Healthy controls were selected among the patients admitted to the hospital for a routine healthy child control without any signs or symptoms and without the history of any auto-inflammatory diseases. Parents of healthy children were informed about the study and asked for participation; and children whose parents accepted the contribution were included in the study. After 8 hours of fasting, blood was obtained from all participants and complete blood sample, serum iron, iron binding capacity, ferritin, vitamin B12 and folic acid levels were studied.

All participants were examined for the evidence of $C D$, with serum tTG IgA levels. In cases with positive results for tTG IgA, duodenum biopsy was obtained with flexible endoscopy to confirm the CD diagnosis and HLA DQ 2 and 8 were studied.

\section{Statistical analysis}

Statistical Package for Social Sciences software (SPSS 17, Chicago, IL, USA) was used for analysis. Descriptive parameters were shown as mean \pm standard deviation or in numbers. Variables were compared using the Student' $t$ test or Mann-Whitney U test. Pearson's chi square test was used to analyze the differences in means and proportions between patients and controls. A $P$ value of $<0.05$ was considered as significant.

\section{RESULTS}

Totally 144 cases, 112 with FMF and 32 healthy control cases were included in the study. The demographic features and laboratory data of study participants are summarized in Table 1.

TABLE 1 . The demographic features and laboratory data of study participants

\begin{tabular}{lccc}
\hline & FMF $(\mathrm{n}=112)$ & Control $(\mathrm{n}=32)$ & $\boldsymbol{P}$ \\
\hline Age (months) & $122.6 \pm 41.4$ & $123.2 \pm 41.6$ & 0.91 \\
Male / Female & $52 / 60$ & $16 / 16$ & 0.71 \\
Hemoglobin $(\mathrm{mg} / \mathrm{dL})$ & $12.5 \pm 1.1$ & $12.6 \pm 1.5$ & 0.74 \\
MCV & $78.6 \pm 6.6$ & $80.2 \pm 5.6$ & 0.38 \\
Iron & $69.0 \pm 31.8$ & $66.8 \pm 36.3$ & 0.84 \\
Iron binding capacity & $312.7 \pm 67.4$ & $304.0 \pm 55.7$ & 0.63 \\
Ferritin & $28.5 \pm 25.1$ & $47.3 \pm 38.3$ & 0.13 \\
Vitamin B12 & $478.7 \pm 319.3$ & $499.0 \pm 255.7$ & 0.80 \\
Folic acid & $9.6 \pm 3.2$ & $9.9 \pm 3.3$ & 0.77 \\
Cases with celiac disease & $3(2.7 \%)$ & $1(3.1 \%)$ & 0.81 \\
\hline
\end{tabular}

FMF: Familial Mediterranean Fever; MCV: Mean corpuscular volume
In FMF group, the mean age at the diagnosis of FMF was $29.5 \pm 20.7$ months and the FMF cases were on colchicine treatment for $849.6 \pm 534.3$ days at the time of this study. Among FMF cases, 28 were homozygote, 59 were heterozygote, 9 were compound heterozygote and 8 cases had 2 different mutations. On the other hand no FMF gene mutations were determined in eight cases. Among those mutations the most common one was the M694 V ( $=40)$ mutations followed by E148 ( $n=28)$ (Table 2). In evaluation of FMF cases, arthralgia was present in three cases and arthritis was reported in 57 cases. The most commonly effected joint was the ankle $(n=41)$ followed by the knee $(n=12)$ joint (Table 3$)$.

tTG IgA positivity was determined in three cases with FMF and in one case in control group. In that aspect there was no significant difference regarding the tTG IgA positivity between groups $(P=0.81)$ (Table 1, Figure 1). Duodenum biopsy performed to the tTG IgA positive cases and revealed Marsh Type 3b in two FMF cases and Marsh Type $3 \mathrm{c}$ in the other one while the biopsy result of the only tTG IgA positive case in control group was Marsh Type $3 b$ (Table 4). In HLA

TABLE 2. Genetic Profile of Familial Mediterranean Fever cases

\begin{tabular}{lcc}
\hline & Number of cases & Percentage \\
\hline Homozygous & 28 & 25.0 \\
Heterozygous & 59 & 52.7 \\
Compound heterozygous & 9 & 8.0 \\
Two different mutations & 8 & 7.1 \\
Without mutations & 8 & 7.1 \\
\hline
\end{tabular}

TABLE 3. Symptoms of Familial Mediterranean Fever cases at admission

\begin{tabular}{lcc}
\hline & $\begin{array}{c}\text { Number of cases with } \\
\text { this symptom }\end{array}$ & Percentage \\
\hline Abdominal pain & 104 & 92.9 \\
Arthritis & 60 & 53.6 \\
Thoracic pain & 28 & 25.0 \\
Skin eruptions & 2 & 1.8 \\
\hline
\end{tabular}

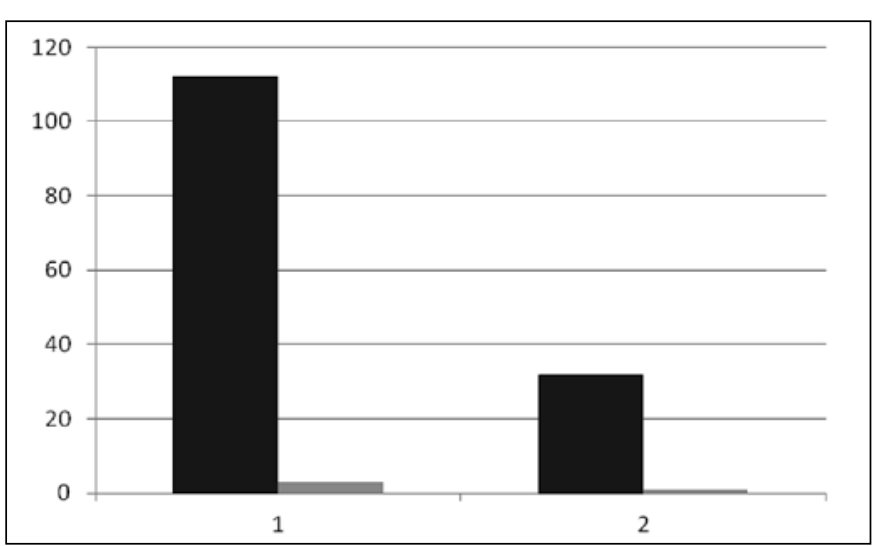

FIGURE. 1. Study participants with and without celiac disease. Black lines are the study participants; 1: Familial Mediterranean fever group and 2: Control group; black lines show the cases with celiac disease in these groups 
TABLE 4. Characteristics of cases diagnosed with celiac disease

\begin{tabular}{lccccc}
\hline & Age (months) & Gender & Biopsy & HLA DQ2 & HLA DQ8 \\
\hline 1st case of FMF group & 156 & $\mathrm{~F}$ & Marsh 3c & Negative & Positive \\
2nd case of FMF group & 144 & $\mathrm{~F}$ & Marsh 3b & Positive & Negative \\
3rd case of FMF group & 29 & $\mathrm{M}$ & Marsh 3b & Positive & Negative \\
1st case of control group & 72 & $\mathrm{~F}$ & Marsh 3b & Positive & Negative \\
\hline
\end{tabular}

FMF: Familial Mediterranean Fever

evaluation of the celiac cases; HLA DQ2 was present in two celiac cases of the FMF group and in the only celiac case of the control group while HLA DQ8 was present in one celiac case of the FMF group.

Since the number of patients with the diagnosis of CD was very low, correlation analysis could not be performed.

When those four cases diagnosed with celiac disease were evaluated; three of them were female while one of them was male. The mean age of them was 100.2 months and the mean age of the disease was 68 months in CD cases with concomitant FMF. Interestingly, iron, vitamin B12 or folate deficiency was not determined in any of the cases.

\section{DISCUSSION}

In this study we aimed to determine the association of FMF with CD, if present. However, we did not determine any relationship between these two immune mediated diseases. The prevalence of CD among FMF cases was 3/112 (2.7\%) and the prevalence of $\mathrm{CD}$ among control cases was $1 / 32$ $(3.1 \%)$ and the difference did not make any sense statistically. In that aspect although these diseases are both immune mediated and sharing common clinical features, different genetic predispositions together with different immunological pathways and responses may be the cause of this result.

There are some case reports in literature about the association of FMF with CD. Krums et al. ${ }^{(13)}$ reported a 33-yearold man who suffered from FMF and CD. A 3 year old girl with both FMF and CD was also reported ${ }^{(20)}$. Similarly, a 14 year old girl with recurrent arthritis was also reported to have $\mathrm{CD}$ in association with $\mathrm{FMF}^{(14)}$. Bass et al. ${ }^{(2)}$ presented a patient with type 1 diabetes mellitus associated with FMF who also had autoimmune thyroid disease and celiac disease. Interestingly Yilmaz et al. ${ }^{(27)}$ described the case of a female patient with FMF under long-term colchicine treatment who presented with severe diarrhea due to gluten-related enteropathy and they hypothesized that long-term colchicine treatment may have intensified the severity of malabsorption in FMF patients with underlying CD.

On the other hand, similar with our study, in a study of Kuloglu et al. ${ }^{(15)}, 50$ children with FMF were examined for the evidence of $\mathrm{CD}$, with antigliadin antibodies IgA, antigliadin antibodies IgG, and anti-endomysial antibodies IgA and 17 children with $C D$ were evaluated for the presence of clinical and laboratory features of FMF and six predominant mutation analysis for MEFV gene. In that study none of the patients in FMF group were diagnosed with CD and none of the patients in CD group had complaints consistent with FMF. Although four patients with $\mathrm{CD}$ were carrying heterozygous MEFV mutations, MEFV had heterozygous frequency in patients with $\mathrm{CD}$ was defined as similar to the normal population in Turkey. In conclusion this study did not reveal any association between $\mathrm{CD}$ and $\mathrm{FMF}^{(15)}$.

FMF and $\mathrm{CD}$ are both genetically determined immune mediated diseases. $\mathrm{T}$ cells, both $\mathrm{CD} 4+$ and $\mathrm{CD} 8+$ gluten specific $\mathrm{T}$ cell clones within the small intestinal mucosa, are key players in the pathogenesis of $\mathrm{CD}^{(8)}$. An up-regulation of the pro-inflammatory cytokine interferon (IFN)-gamma and the down-regulatory cytokine interleukin (IL)-10, which is caused by T cells, contribute to the CD disease activation ${ }^{(5)}$. On the other hand, in FMF patients increased transcription of the pro-inflammatory cytokines (TNF- $\alpha$, IL-6 and IL-8) has been reported ${ }^{(19)}$.

Familial Mediterranean Fever is an auto-inflammatory disease and it has also been reported to occur together with some other autoimmune disorders, such as systemic Lupus erythematosus, rheumatoid arthritis and Hashimoto's thyroiditis $^{(3,6,22)}$. It is also clear that, $\mathrm{CD}$ is an autoimmune disease and related to many autoimmune conditions including thyroid autoimmunity, dermatitis herpetiformis, and Type 1 diabetes mellitus ${ }^{(16,26)}$.

Although some case reports are present, any association of these two common entities, FMF and CD, has not been reported yet and we also did not determine any relationship.

There are some limitations of this study that should be mentioned. The study population was not large enough to make a generalization. On the other hand, since the number of patients with $C D$ was very low, we could not make any correlation analysis. With a larger study population, correlation analysis may reveal an association of $\mathrm{CD}$ with the disease age, colchicine usage time, or genetic mutations, if present.

In conclusion, we did not determine an association of FMF with CD. Larger studies with any subgroup analysis are warranted to determine the relationship of these two diseases.

\section{Author contribution}

Iş1kay S participated in the concept, design, supervision, data collection and/or processing, analysis and/or interpretation, literature search, writing and critical review. Işıkay $\mathrm{N}$ participated in the design, supervision, analysis and/or interpretation, writing and critical review. Kocamaz $\mathrm{H}$ participated in the resource and data collection and/or processing. 
Işıkay S, Işıkay N, Kocamaz H. Prevalência da doença celíaca entre pacientes com Febre Familiar do Mediterrâneo. Arq Gastroenterol. 2015,52(1):55-8.

RESUMO - Contexto - A Febre Familiar do Mediterrâneo e a doença celíaca são ambas relacionadas com auto-inflamação e/ou auto-imunidade e partilham algumas características clínicas comuns tais como dor abdominal, diarréia, distensão abdominal e flatulência. Objetivo - Determinar a associação destas duas doenças, se presente. Métodos - Um total de 112 pacientes diagnosticados com Febre Familiar do Mediterrâneo e 32 casos como controle saudável foram incluídos no estudo. Todos os participantes foram examinados para a evidência da doença celíaca, com níveis de IgA séricos transglutaminase (tTG IgA). Resultados - Um total de 144 casos, 112 com Febre Familiar do Mediterrâneo e 32 casos controle saudável foram incluídos no estudo. A positividade tTG IgA foi determinada em três casos com Febre Familiar do Mediterrâneo e em um caso no grupo controle. Neste aspecto não há nenhuma diferença significativa em relação a positividade tTG $\operatorname{IgA}$ entre os grupos $(P=0,81)$. Biópsia de duodeno realizado para os casos positivos de tTG IgA e revelou Marsh tipo 3b em dois casos de Febre Familiar e Marsh tipo 3C no outro, enquanto o resultado da biópsia do único caso positivo tTG IgA no grupo controle foi Marsh tipo 3b. Na avaliação de HLA dos casos de doença celíaca, HLA DQ2 esteve presente em dois casos de doença celíacas do grupo Febre Familiar do Mediterrâneo e no caso celíaco do grupo controle, enquanto HLA-DQ8 estava presente em um caso de doença celíaca do grupo Febre Familiar do Mediterrâneo. Conclusão - Não se determinou uma associação de Febre Familiar do Mediterrâneo com doença celíaca. Maiores estudos com análise de subgrupo são necessários para determinar a relação entre estas duas doenças.

DESCRITORES - Febre Familiar do Mediterrâneo. Doença celíaca. Criança.

\section{REFERENCES}

1. Ancient missense mutations in a new member of the RoRet gene family are likely to cause familial Mediterranean fever. The International FMF Consortium. Cell. 1997;90(4):797-807.

2. Baş F, Kabataş-Eryilmaz S, Günöz H, Darendeliler F, Küçükemre B, Bundak R, et al Type 1 diabetes mellitus associated with autoimmune thyroid disease, celiac disease and familial Mediterranean fever: case report. Turk J Pediatr. 2009;51(2):183-6.

3. Birlik M, Tunca M, Hizli N, Soytürk M, Yeniçerioğlu Y, Ozcan MA, et al. Coexistence of familial Mediterranean fever with sacroiliitis and Behçet's disease: a rare occurrence. Clin Rheumatol 1998;17:397-9.

4. DePaolo RW, Abadie V, Tang F, Fehlner-Peach H, Hall JA, Wang W, et al. Co-adjuvant effects of retinoic acid and IL-15 induce inflammatory immunity to dietary antigens. Nature 2011;471 (7337):220-4

5. Di Sabatino A, Corazza GR. Coeliac disease. Lancet. 2009;373 (9673):1480-93.

6. Ergul AB, Dursun I, Torun YA. Hashimoto's thyroiditis in a child with familial Mediterranean fever: a case report. Iran J Pediatr. 2013;23(4):489-90.

7. Ganji A, Esmaielzadeh A, Aafzal Aghayee M, Goshayeshi L, Ghaffarzadegan K. The clinical presentation of celiac disease: experiences from northeastern iran. Middle East J Dig Dis. 2014;6(2):93-7.

8. Garrote JA, Gómez-Gonzale'z E, Bernardo D, Arranz E, Chirdo F. Celiac disease pathogenesis: The proinflammatory cytokine network. J Pediatr Gastroenterol Nutr. 2008;47(Suppl 1):27-32.

9. Góra-Gębka M, Woźniak M, Cielecka-Kuszyk J, Korpal-Szczyrska M, Sznurkowska K, Zagierski M, et al. Graves' disease, celiac disease and liver function abnormalities in a patient - clinical manifestation and diagnostic difficulties. Acta Biochim Pol. 2014;61(2):281-4.

10. Han A, Newell EW, Glanville J, Fernandez-Becker N, Khosla C, Chien YH, et al Dietary gluten triggers concomitant activation of CD4+ and CD8+ $\alpha \beta$ T cells and $\gamma \delta$ T cells in celiac disease. Proc Natl Acad Sci U S A. 2013;110(32):13073-8.

11. Horcada Rubio ML, Delgado Beltrán C, Armas Ramírez C. Autoinflammatory disorders: a new concept in hereditary periodic fever syndromes. An Med Interna; 2004;21(3):143-7.

12. Kiss MH, Magalhães CS. Autoinflammatory diseases: mimics of autoimmunity or part of its spectrum? Case presentation. J Clin Immunol. 2008;28:84-9.

13. Krums LM, Golovanova EV, Khomeriki SG, Varlamicheva AA, Dorofeev AS Celiac disease is a 33-year-old man with periodic disease. Eksp Klin Gastroenterol. 2012;(3):114-7.
14. Kuloğlu Z, Kansu A, Tutar E, Yalçinkaya F, Ensari A, Girgin N. Association of familial Mediterranean fever and celiac disease in a 14-year-old girl with recurrent arthritis. Clin Exp Rheumatol. 2008;26 (4 Suppl 50):S131.

15. Kuloğlu Z, Ozçakar ZB, Kirsaçlioğlu C, Yüksel S, Kansu A, Girgin N, et al. Is there an association between familial Mediterranean fever and celiac disease? Clin Rheumatol. 2008;27(9):1135-9.

16. Lauret E, Rodrigo L. Celiac disease and autoimmune-associated conditions. Biomed Res Int. 2013;2013:127589.

17. Meloni GF, Thomasi PA, Bertoncelli A, Fanciulli G, Delitala G, Meloni T. Prevalence of silent celiac disease in patients with autoimmune thyroiditis from Northern Sardinia J Endocrinol Invest. 2001;24(5):298-302.

18. Nenna R, Guandalini S, Popp A, Kurppa K. Coeliac disease. Autoimmune Dis. 2014;2014:623784.

19. Notarnicola C, Didelot MN, Seguret F, Demaille J, Touitou I. Enhanced cytokine mRNA levels in attack-free patients with familial Mediterranean fever. Genes Immun 2002;3(1):43-5.

20. Olbjørn C, Fjaerli HO. A three-year-old girl with abdominal pain and fever. Tidsskr Nor Laegeforen. 2010;130(5):494-5.

21. Onen F. Familial Mediterranean Fever. Rheumatol Int. 2006;26(6):489-96.

22. Rabinovich E, Livneh A, Langevitz P, Brezniak N, Shinar E, Pras M, et al. Severe disease in patients with rheumatoid arthritis carrying a mutation in the Mediterranean fever gene. Ann Rheum Dis. 2005;64(7):1009-14.

23. Rostom A, Dube C, Cranney A, Saloojee N, Sy R, Garritty C, et al. Celiac disease Evid Rep Technol Assess (Summ). 2004;(104):1-6.

24. Rubio-Tapia A, Hill ID, Kelly CP, Calderwood AH, Murray JA. American College of Gastroenterology.ACG clinical guidelines: diagnosis and management of celiac disease. Am J Gastroenterol 2013;108(5):656-76.

25. Savic S, Dickie LJ, Battellino M, McDermott MF. Familial Mediterranean fever and related periodic fever syndromes/autoinflammatory diseases. Curr Opin Rheumatol 2012;24(1):103-12.

26. van der Pals M, Ivarsson A, Norström F, Högberg L, Svensson J, Carlsson A. Prevalence of thyroid autoimmunity in children with celiac disease compared to healthy 12-year olds. Autoimmune Dis. 2014;2014:417356.

27. Yilmaz Y, Baran B, Seniz NB, Dolar E. Familial Mediterranean fever coexisting with celiac disease: is there a link with long-term colchicine treatment? J Gastrointestin Liver Dis. 2009;18(1):119-20. 